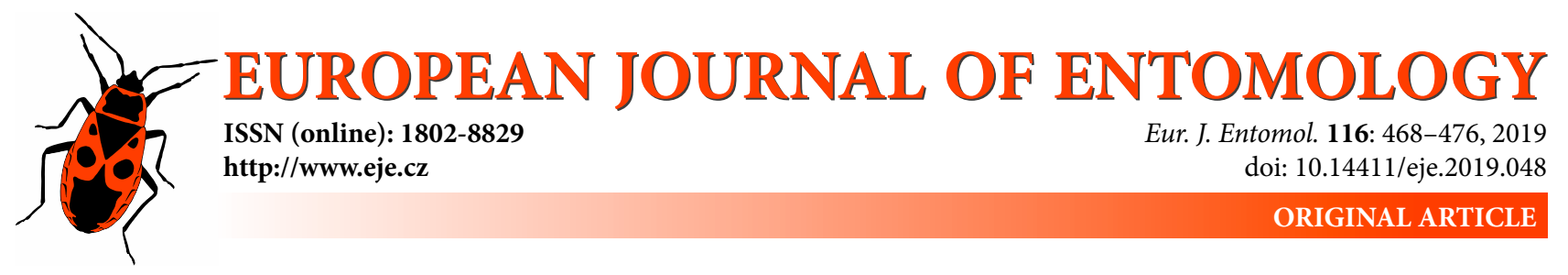

\title{
Sexual differences in the morphology and movement of a butterfly: Good shape does not make good dispersers
}

\author{
Elisabeth REIM ${ }^{1}$, Fee WIDDERICH ${ }^{1}$ and KLAus FISCHER ${ }^{2}$ \\ ${ }^{1}$ Zoological Institute and Museum, Greifswald University, Soldmannstraße 14, D-17489 Greifswald, Germany; \\ e-mail: elisabeth.reim@uni-greifswald.de,f.widderich@hotmail.de \\ ${ }^{2}$ Institute for Integrated Natural Sciences, University Koblenz-Landau, Universitätsstraße 1, D-56070 Koblenz, Germany; \\ e-mail: Klausfischer@uni-koblenz.de
}

Key words. Lepidoptera, Lycaenidae, Lycaena tityrus, dispersal, flight capacity, flight performance, sexual dimorphism, territoriality

\begin{abstract}
Movements are involved in several routine processes and may scale up to important ecological processes such as dispersal. However, movement is affected by a wealth of factors including flight capacity and behavioural traits. Both frequently differ in the sexes, which may well affect movement. We here aim to disentangle the relative importance of sexual differences in flight capacity versus behaviour on small-scale movements under controlled laboratory conditions in the temperate-zone butterfly Lycaena tityrus. The morphology of males is typically associated with increased flight capacity in this species. Nevertheless, the flight performances of the sexes did not differ, but the mobility of the females was higher. Thus, flight capacity and patterns of movement may not be intimately associated. Rather, the costs and benefits of flight seem to differ substantially between the sexes, with females being more mobile, potentially as a risk spreading strategy, while males are territorial and thus more sedentary. Thus, predictions regarding movement based on morphology are difficult.
\end{abstract}

\section{INTRODUCTION}

Movements affect several routine processes such as foraging, mate location and reproduction (Berwaerts \& Van Dyck, 2004; Van Dyck \& Baguette, 2005). Ultimately, this may influence important ecological processes including population connectivity, gene flow or range shift, provided there is a link between movements and dispersal (Bohonak, 1999; Ronce, 2007; Bonte et al., 2012; Matthysen, 2012; Saastamoinen et al., 2018). Movements and thus potentially dispersal though are affected by many external and internal factors. External factors comprise e.g. habitat quality and abiotic conditions such as temperature (Legrand et al., 2015; Kuussaari et al., 2016). Regarding internal factors, movements are often related to flight performance in insects, which is in turn associated with morphological traits. Examples of such traits are wing size, wing aspect ratio, body mass, wing loading, thorax mass, thorax-abdomen ratio, and energy reserves (Betts \& Wootton, 1988; Berwaerts et al., 2002; Niitepõld et al., 2009; Ducatez et al., 2012; Therry et al., 2014).

The above mentioned internal traits basically reflect an individual's condition, i.e. the morphological and physiological capacity to fly. For instance, it has been shown that increased wing size, thorax mass, thorax-abdomen ratio, and storage reserves as well as decreased wing load- ing promote flight performance, and therefore potentially movement and dispersal (Hill et al., 1999; Dudley, 2000; Hughes et al., 2003; Almbro \& Kullenberg, 2012; Legrand et al., 2015). Often, males and females differ substantially in these traits, suggesting differential selection on flightrelated traits among sexes (Gilchrist, 1990; Berwaerts et al., 2002, 2006; Van Dyck \& Wiklund, 2002; Ducatez et al., 2014). However, sexual differences may extend well beyond morphology, as sexes may differ with regard to the costs and benefits of movement and dispersal (Berwaerts et al., 2006). Thus, apart from flight capacity, behavioural traits such as exploration, territoriality, aggression and sociability, which may well differ in the sexes, may affect the intrinsic motivation to move and disperse (Dingemanse et al., 2003; Duckworth \& Badyaev, 2007; Cote et al., 2010a; Ducatez et al., 2012). For instance, individual variation in exploratory behaviour has been linked to variation in dispersal propensity, with explorative individuals being more likely to disperse (Fraser et al., 2001; Dingemanse et al., 2003; Cote et al., 2010b).

In this study we investigate small-scale patterns in movements (time until take-off, number of positions visited and distance moved), flight performance (endurance under stress) and morphology in males and females of the temperate-zone butterfly Lycaena tityrus under laboratory 
conditions. We predict that (1) males have morphologies associated with increased flight performance and (2) a concomitantly increased flight performance, while (3) females are more mobile. Hypotheses (1) and (2) are based on previous findings on other butterflies, showing that males have typically a better flight performance than females (Berwaerts et al., 2002; Saastamoinen et al., 2012; Ducatez et al., 2014). However, females may nevertheless be the more dispersive sex in butterflies (hypothesis 3), because of the need to spread the risk when ovipositing, while males are often territorial, as is the case in L. tityrus, and thus more sedentary than females (Ebert \& Rennwald, 1991; Fischer et al., 1999; Hopper, 1999; Fischer \& Fiedler, 2000a). We thus aim to disentangle the relative importance of flight capacity versus sex-specific behavioural differences for movement under controlled laboratory conditions. This issue, i.e. the potentially important role of variation in behavioural traits in addition to flight capacity for movement is ecologically important but requires further investigation (e.g. Cote et al., 2010a; Réale et al., 2010; Steyn et al., 2016).

\section{MATERIAL AND METHODS}

\section{Study organism and animal rearing}

Lycaena tityrus (Poda, 1761) is a widespread temperate-zone butterfly with a range from Western Europe to central Asia (Ebert \& Rennwald, 1991). It is currently expanding its range towards higher latitudes and altitudes, which is assumed to be largely driven by anthropogenic climate change (Brunzel et al., 2008; Settele et al., 2008). This species is bivoltine with two discrete generations per year in most parts of its range, although populations with one or three generations per year occur. Larvae of the last brood enter diapause, overwintering as half-grown larvae in the third instar. The principal larval host-plant is Rumex acetosa L. (Polygonaceae), but some congeneric Rumex species are utilized as well (Ebert \& Rennwald, 1991; Tolman \& Lewington, 1998; Settele et al., 2008). Adults are nectar feeders, using a wide array of species including several Asteraceae (Ebert \& Rennwald, 1991). For this study, offspring (F1) of 30 first-generation female butterflies collected in June 2016 from a population in north-eastern Germany, i.e. near the city of Greifswald, were used. Larvae were reared under conditions inducing diapause, and subsequently kept in a climate cabinet at a constant temperature of $2^{\circ} \mathrm{C}(8 \mathrm{~L}: 16 \mathrm{D})$ for hibernation. After a diapause of about 9 months, larvae were reared under controlled environmental conditions (i.e. $22^{\circ} \mathrm{C}, 70 \%$ relative humidity, $12 \mathrm{~L}: 12 \mathrm{D}$ cycle) until pupation. Throughout, larvae were reared individually in small plastic boxes $(125 \mathrm{~mL})$ and had access to an ample supply of food. Boxes contained moistened filter paper and fresh cuttings of the host plant ( $R$. acetosa and acetosella). Resulting pupae were transferred to a climate cabinet set at $15^{\circ} \mathrm{C}(60 \%$ r.h., $18 \mathrm{~L}: 6 \mathrm{D})$ in order to retard further development. One day before the start of the respective experiment, pupae were transferred in batches of 40 each to $28^{\circ} \mathrm{C}$ to facilitate quick and synchronized adult emergence. Resulting adult butterflies were weighed at emergence (emergence mass), and were afterwards used to investigate the effects of sex and various morphological and physiological traits on flight behaviour and performance in captivity. Thus, we exclusively used laboratory-reared animals to effectively control for environmentally induced variation among individuals. Note that as a consequence phenotypes may differ to some extent from the ones found in nature.

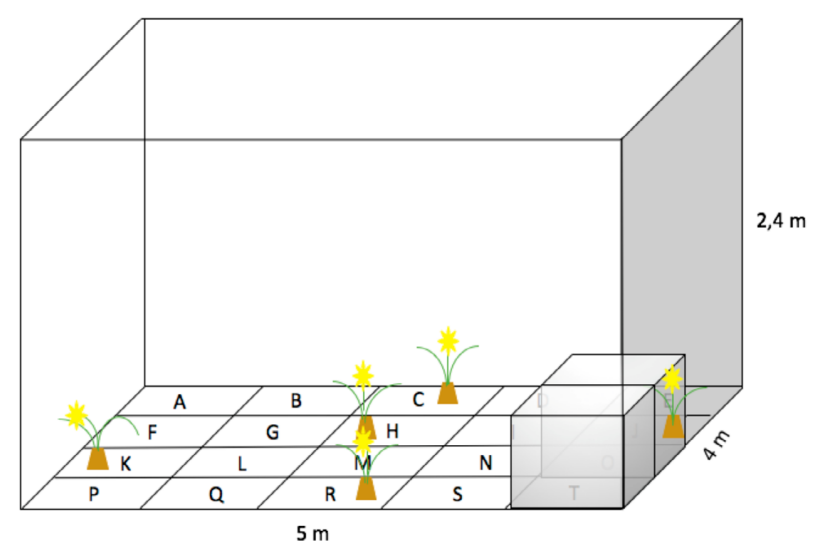

Fig. 1. Diagram of the experimental chamber $\left(48 \mathrm{~m}^{3}\right)$ showing the positions of the squares on the ground and feeding sites. The cages containing the Lycaena tityrus individuals were placed on squares $\mathrm{O}$ and $\mathrm{T}$.

\section{Flight behaviour}

The freshly emerged butterflies were individually marked on their left hindwing, males and females were separated and placed into population cages $(50 \times 50 \times 50 \mathrm{~cm})$. On the following day, cages with butterflies were transferred to an experimental chamber $\left(28^{\circ} \mathrm{C}, 60 \%\right.$ r.h. $)$ and allowed $1 \mathrm{~h}$ to acclimatize before the start of a trial. The volume of the chamber was $48 \mathrm{~m}^{3}(5 \times 4 \times 2.4$ $\mathrm{m})$. The small size may certainly bias the results obtained. However, it is a standard method for estimating small-scale movements in butterflies (e.g. Saastamoinen \& Hanski, 2008; Saastamoinen et al., 2012; Reim et al., 2018b, 2019b). The ground area was divided into 20 squares of $1 \times 1 \mathrm{~m}$ each, which were marked with letters (A-T). Five feeding sites were established, with each site providing fresh flowers, oviposition plants, water and a highly concentrated sucrose solution (Fig. 1). At 10 a.m., population cages were opened and the position (square A-T) of each butterfly was recorded every 15 min for $6 \mathrm{~h}$, starting at 10.15 a.m. Observations were made by a single person as careful as possible in order to minimise their effect on the animals' behaviour. The positions of butterflies sitting on the wall or ceiling were assigned to the respective ground field, because most butterflies stayed near the ground. After $6 \mathrm{~h}$ of observation, butterflies were caught and subjected to a flight performance test (see below). Five such climate chamber trials were carried out consecutively, resulting in a total of 180 tested butterflies (as on the last day only 20 instead of 40 butterflies were available for testing). We calculated for each butterfly (1) the number of squares visited, (2) total distance moved and (3) step length. To calculate the total distance, we summed all individual movements recorded during the observation based on the centres of the squares approached. Step length was calculated as the total distance divided by the number of squares visited.

\section{Flight performance: Vortex test}

Butterflies were tested for flight performance using a well-established assay, which was designed to observe a forced activity under stressful conditions comparable to short stressful situations in the wild (cf. Ducatez et al., 2012, 2013). Each individual was placed in a plastic chamber $(30 \times 16 \times 14 \mathrm{~cm})$, which was perforated at its base and fixed to a rapid agitator (IKA Vortex 4 digital). After a habituation period of $30 \mathrm{~s}$, the vortex was switched on to strongly shake the chamber, preventing the butterfly from holding onto the walls. Thus, during the test, butterflies had to fly or were lying at the bottom of the shaking chamber. The time an individual butterfly spent flying was recorded for $60 \mathrm{~s}$, with 
higher values reflecting a better flight performance. This essay has been repeatedly shown to be correlated with mobility and dispersal (e.g. Ducatez et al., 2012; Legrand et al., 2015). Experiments were performed in the same experimental chamber as above (see flight behaviour), using identical conditions. After the performance test, butterflies were frozen in liquid nitrogen for later analyses of potentially flight-related parameters.

\section{Morphological and physiological analyses}

First, adult body mass was determined to the nearest 0.01 $\mathrm{mg}$ (Sartorius CPA225D). Then, head, legs and wings were removed, and thorax and abdomen separated and afterwards also weighed. Abdomen fat content was measured following Fischer et al. (2003), but using the less poisonous acetone instead of dichloromethane. Therefore, abdomens were first dried to constant weight for two days at $70^{\circ} \mathrm{C}$. Abdomen dry mass was measured. Afterwards, fat was extracted twice for $48 \mathrm{~h}$ each, using $1 \mathrm{ml}$ of acetone $\left(\mathrm{C}_{3} \mathrm{H}_{6} \mathrm{O}\right)$ per butterfly. Solutions were exchanged between both fat extractions. Then, abdomens were dried again for two days at $70^{\circ} \mathrm{C}$, after which the fat-free dry mass was measured. Absolute (mg) and relative (\%) fat contents were determined as the mass difference between abdomen dry mass and the remaining dry mass after the two fat extractions. Forewing length (from basis to apex) and area were measured using digital images of the undersides of left forewings (photographed using a digital camera mounted on a stereo microscope) and NIS elements software 3.22.15 (Nikon, Tokio, Japan). Wing loading was calculated as total body mass divided by forewing area and wing aspect ratio as $4 \times$ forewing length ${ }^{2}$ divided by the forewing area (Berwaerts

Table 1. Results of principal component analyses for males (a) and females (b), including Eigen values, percentages of the variance explained, cumulative percentages of the variance explained, and $r$-values of correlations with continuous variables for principal components $1-4$, respectively. r-values $>0.6$ in bold.

\begin{tabular}{lccccc}
\hline No. & Parameter & PC1 & PC2 & PC3 & PC4 \\
\hline a-males & & & & & \\
\hline 1 & Eigen value & 5.2 & 1.8 & 1.6 & 1.1 \\
2 & Variance explained (\%) & 47.7 & 16.6 & 14.5 & 10.2 \\
3 & Cumulative variance (\%) & 47.7 & 64.3 & 78.8 & 89.0 \\
4 & Adult mass at emergence & $-\mathbf{0 . 7 7 8}$ & -0.253 & -0.128 & 0.006 \\
5 & Adult body mass & $-\mathbf{0 . 9 6 1}$ & -0.190 & 0.007 & 0.024 \\
6 & Abdomen mass & $-\mathbf{0 . 9 0 0}$ & -0.368 & 0.158 & -0.057 \\
7 & Thorax mass & $-\mathbf{0 . 7 7 6}$ & 0.099 & -0.387 & 0.308 \\
8 & Thorax-abdomen ratio & 0.396 & 0.393 & $-\mathbf{0 . 6 0 6}$ & 0.437 \\
9 & Fat (mg) & -0.583 & $\mathbf{0 . 6 0 8}$ & 0.473 & 0.210 \\
10 & Fat (\%) & -0.337 & $\mathbf{0 . 6 9 4}$ & 0.567 & 0.258 \\
11 & Wing length & $-\mathbf{0 . 7 1 4}$ & 0.250 & -0.496 & -0.012 \\
12 & Wing area & $-\mathbf{0 . 7 2 8}$ & 0.392 & -0.423 & -0.323 \\
13 & Wing loading & $-\mathbf{0 . 7 7 7}$ & -0.452 & 0.248 & 0.207 \\
14 & Aspect ratio & 0.224 & -0.397 & -0.061 & 0.758 \\
\hline $\mathrm{b}-$ females & & & & \\
\hline 1 & Eigen value & 4.7 & 2.1 & 1.7 & 1.0 \\
2 & Variance explained (\%) & 43.0 & 19.1 & 15.7 & 8.8 \\
3 & Cumulative variance (\%) & 43.0 & 62.1 & 77.8 & 86.6 \\
4 & Adult mass at emergence & $-\mathbf{0 . 6 3 1}$ & 0.119 & -0.064 & 0.494 \\
5 & Adult body mass & $-\mathbf{0 . 9 5 8}$ & 0.183 & -0.030 & -0.074 \\
6 & Abdomen mass & $-\mathbf{0 . 8 2 1}$ & 0.464 & 0.217 & -0.007 \\
7 & Thorax mass & $-\mathbf{0 . 7 8 9}$ & -0.135 & -0.294 & -0.162 \\
8 & Thorax-abdomen ratio & 0.542 & -0.398 & -0.535 & 0.013 \\
9 & Fat (mg) & -0.512 & $-\mathbf{0 . 6 5 8}$ & 0.446 & -0.251 \\
10 & Fat (\%) & -0.241 & $-\mathbf{0 . 7 9 1}$ & 0.431 & -0.260 \\
11 & Wing length & -0.573 & -0.278 & $-\mathbf{0 . 6 9 2}$ & -0.084 \\
12 & Wing area & $-\mathbf{0 . 6 5 8}$ & -0.462 & -0.474 & 0.243 \\
13 & Wing loading & $\mathbf{- 0 . 8 4 0}$ & 0.391 & 0.145 & -0.183 \\
14 & Aspect ratio & $\mathbf{0 . 1 9 7}$ & 0.397 & -0.440 & -0.677 \\
\hline \multicolumn{7}{r}{} & & & & &
\end{tabular}

et al., 2002). Thorax-abdomen ratio was calculated by dividing thorax through abdomen mass.

\section{Statistical analyses}

Sexual differences in morphological, physiological, and flight parameters were analysed using the Mann-Whitney U-test. To test for the effects of continuous variables (morphology, physiology) on flight parameters, we first performed principal component analyses (PCAs), owing to the strong inter-correlations among traits (Table A1). PCAs were calculated separately for males and females, as sexes differed strongly in a variety of traits (see below). We used the first four principal components (PCs) for further analyses, having Eigenvalues between 1.1 and 5.2 for males (Table 1a) and 1.0 and 4.7 for females (Table 1b). Thus, all PCs explaining $\geq 8.8 \%$ of the variance were included. Data on flight behaviour (number of squares, total distance and step length) were analysed using general linear models, using test day, the respective PCs and flight performance as covariates, followed by a stepwise backwards elimination of non-significant factors. Data on flight performance were analysed in a similar way. Differences in the spatial distribution of males and females within the climatic chamber (based on the number of observations per square) were determined using $\mathrm{Chi}^{2}$-tests. Please note that we did not consider family effects to account for the non-independency of the offspring produced by a specific mother throughout, as we did not record to which family individuals belonged. However, please also note the high number of founding females (30) relative to the number of individuals tested (180). Therefore, any potentially confounding effects due to this neglected source of variation should be small. All statistical tests were performed using Statistica 12.0 (Tulsa, StatSoft, OK). All means are given \pm 1 SE.

\section{RESULTS}

Significant sex differences were found for all morphological and physiological traits except forewing length (Table 2), indicating that females had on average a higher abdomen and adult body mass, wing loading, and a higher absolute but lower relative fat content, lower thorax mass, thorax-abdomen ratio, and wing aspect ratio, and larger

Table 2. Mann-Whitney U-test results for sexual differences in morphological, physiological and flight parameters in Lycaena tityrus. Given are means \pm 1 SE. Group sample sizes range between 63 and 115 individuals.

\begin{tabular}{lrrrr}
\hline Parameters & $\mathrm{Z}$ & \multicolumn{1}{c}{ Females } & \multicolumn{1}{c}{ Males } & $\mathrm{P}$ \\
\hline Morphology & & & & \\
Adult mass [mg] & -6.7 & $61.9 \pm 1.30$ & $51.8 \pm 0.99$ & $<\mathbf{0 . 0 0 0 1}$ \\
at emergence & & & & \\
Adult body mass [mg] & -8.4 & $52.0 \pm 1.03$ & $39.5 \pm 0.78$ & $<\mathbf{0 . 0 0 0 1}$ \\
Abdomen mass [mg] & -10.5 & $24.4 \pm 0.65$ & $10.8 \pm 0.49$ & $<\mathbf{0 . 0 0 0 1}$ \\
Thorax mass [mg] & 3.0 & $19.1 \pm 0.42$ & $20.6 \pm 0.32$ & $\mathbf{0 . 0 0 2 6}$ \\
Thorax-abdomen ratio & 10.6 & $0.8 \pm 0.05$ & $2.1 \pm 0.03$ & $<\mathbf{0 . 0 0 0 1}$ \\
Wing length [mm] & -1.5 & $15.7 \pm 0.07$ & $15.6 \pm 0.05$ & 0.1376 \\
Wing area [mm²] & -7.4 & $102.1 \pm 0.87$ & $92.2 \pm 0.66$ & $<\mathbf{0 . 0 0 0 1}$ \\
Wing loading & -7.4 & $50.9 \pm 0.92$ & $42.7 \pm 0.70$ & $<\mathbf{0 . 0 0 0 1}$ \\
Aspect ratio & 10.3 & $9.7 \pm 0.04$ & $10.6 \pm 0.03$ & $<\mathbf{0 . 0 0 0 1}$ \\
\hline Physiology & & & & \\
Fat [mg] & -5.7 & $1.2 \pm 0.06$ & $0.69 \pm 0.04$ & $<\mathbf{0 . 0 0 0 1}$ \\
Fat [\%] & 6.0 & $12.4 \pm 0.83$ & $18.8 \pm 0.63$ & $<\mathbf{0 . 0 0 0 1}$ \\
\hline Flight & & & & \\
Squares [n] & -2.3 & $7.0 \pm 0.37$ & & $\mathbf{0 . 0 2 2 0}$ \\
Distance [m] & -1.4 & $16.5 \pm 1.05$ & & 0.1745 \\
Step length [m] & 1.2 & $2.3 \pm 0.10$ & & 0.7027 \\
Flight performance [s] & & & & 0.2516 \\
\hline
\end{tabular}



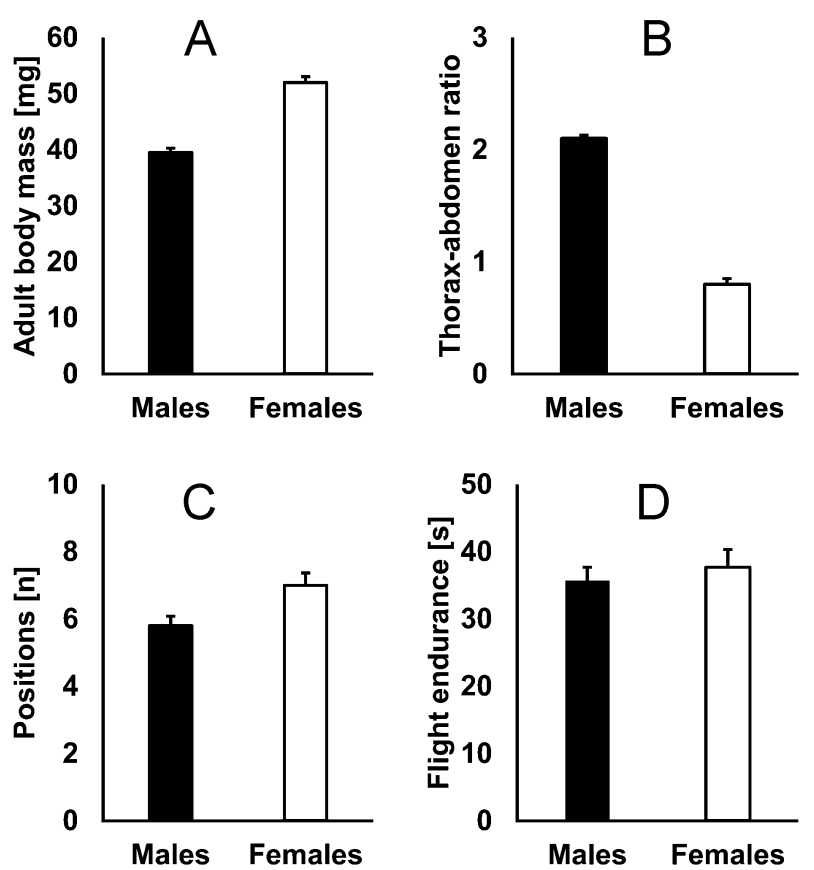

Fig. 2. Adult body mass (A), thorax-abdomen ratio (B), number of squares (positions) visited within a climate cell (C), and flight performance ( $D$, non-significant) of Lycaena tityrus in relation to sex.

wings than males (Fig. 2). A significant sex difference was also found in the number of squares visited, with females approaching more positions than males (Fig. 2C), but not for total distance moved and step length (Table 2).

General linear models for the total distance moved revealed a significant effect of $\mathrm{PC} 1$ in males and a tendency in terms of flight performance in females (Table 3a; see Fig. A1 for plots of significant covariates). The distance moved was positively correlated with PC1 in males (beta $0.28 \pm$ 0.09 ), which was in turn (negatively) correlated with measures of body size. Thus, smaller males flew longer distances. The distance moved tended to be negatively correlated with flight performance in females (beta $-0.26 \pm 0.13$ ). Thus, females covering longer distances in the climate cabinet tended to have (subsequently) a worse performance in the vortex test. The number of squares was significantly affected by $\mathrm{PC} 1$ and $\mathrm{PC} 3$ in males and $\mathrm{PC} 1$ and flight performance in females (Table $3 b$ ). The number of positions was positively correlated with PC1 in males and females (beta $0.31 \pm 0.09$ and $0.32 \pm 0.13$, respectively) and with PC3 in males (beta $0.21 \pm 0.09$ ), but negatively with flight performance in females (beta $-0.29 \pm 0.13$ ). Thus, smaller individuals and males with shorter wings approached more positions, and females that approached more positions had (subsequently) a poorer flight performance. For step length, the models revealed a significant effect of flight performance in males and test day in females (Table 3c). Step length was positively related to flight performance in males (beta $0.19 \pm 0.10$ ). Hence, males with longer steps had a better flight performance, while females only showed significant variation across test days.

Flight performance in females was significantly affected by PC1, while in males no factor was selected (Table 3d).
Table 3. General linear model results for males and females for the effects of test day, PCs 1-4, and flight performance (vortex test) on (a) the total distance moved within a climate cell, (b) the number of squares (positions) visited, (c) the length of steps, and for the effects of PCs 1-4 on the flight performance (d, vortex test) of Lycaena tityrus. Models were constructed for each sex separately using a stepwise backwards elimination of non-significant factors. Only the selected factors are shown in the tables. In Table $3 d$ no factor was selected for males. Significant $p$-values are given in bold.

\begin{tabular}{|c|c|c|c|c|}
\hline (a) & & & & \\
\hline Distance - Males & $M S$ & d.f. & $F$ & $P$ \\
\hline PC1 & 553.4 & 1 & 10.0 & 0.0021 \\
\hline PC3 & 106.1 & 1 & 1.9 & 0.1697 \\
\hline PC4 & 130.8 & 1 & 2.4 & 0.1277 \\
\hline Error & 55.5 & 110 & & \\
\hline Distance - Females & $M S$ & d.f. & $F$ & $P$ \\
\hline Vortex test & 300.8 & 1 & 3.7 & 0.0591 \\
\hline PC1 & 172.2 & 1 & 2.1 & 0.1504 \\
\hline Error & 81.0 & 55 & & \\
\hline \multicolumn{5}{|l|}{ (b) } \\
\hline Squares - Males & $M S$ & d.f. & $F$ & $P$ \\
\hline PC1 & 81.1 & 1 & 11.9 & 0.0008 \\
\hline PC3 & 37.3 & 1 & 5.5 & 0.0209 \\
\hline PC4 & 12.3 & 1 & 1.8 & 0.1818 \\
\hline Error & 6.8 & 109 & & \\
\hline Squares - Females & $M S$ & d.f. & $F$ & $P$ \\
\hline Vortex test & 50.1 & 1 & 5.5 & 0.0229 \\
\hline PC1 & 60.5 & 1 & 6.6 & 0.0129 \\
\hline Error & 9.2 & 59 & & \\
\hline \multicolumn{5}{|l|}{ (c) } \\
\hline Step length - Males & $M S$ & d.f. & $F$ & $P$ \\
\hline Vortex test & 2.9 & 1 & 4.0 & 0.0494 \\
\hline Error & 0.7 & 106 & & \\
\hline Step length - Females & $M S$ & d.f. & $F$ & $P$ \\
\hline Test day & 1.3 & 4 & 4.2 & 0.0049 \\
\hline Error & 0.3 & 59 & & \\
\hline \multicolumn{5}{|l|}{ (d) } \\
\hline Vortex test - Females & $M S$ & d.f. & $F$ & $P$ \\
\hline PC1 & 1632.5 & 1 & 4.7 & 0.0338 \\
\hline PC4 & 1145.1 & 1 & 3.3 & 0.0739 \\
\hline Error & 345.8 & 59 & & \\
\hline
\end{tabular}

Flight performance and $\mathrm{PC} 1$ were positively related in females (beta $0.27 \pm 0.12$ ), which was in turn (negatively) correlated with measures of body size. Thus, smaller females had a better flight performance. Additionally, PC4 tended to positively affect flight performance in females (beta $0.22 \pm 0.12$ ). PC4 in turn was most strongly (positively) correlated with aspect ratio, hence a higher aspect ratio increased flight performance in females.

The distribution of butterflies within the experimental chamber was not even $\left(\mathrm{Chi}^{2}=386.4, \mathrm{p}<0.0001\right.$, Table A3). The most frequented field was $P$, which was not a feeding site (cf. Fig. 1). In general, the peripheral fields were preferred over the central fields, while feeding sites were not generally preferred. Separate analyses for females and males revealed similar results (females: $\mathrm{Chi}^{2}=252.2$, $\mathrm{p}<0.0001$; males: $\mathrm{Chi}^{2}=159.3, \mathrm{p}<0.0001$; Table A3). Overall, the distribution of both sexes was strongly positively correlated $(\mathrm{r}=0.92, \mathrm{p}<0.0001, \mathrm{n}=20)$. 


\section{DISCUSSION}

\section{Sexual differences in morphological traits}

Our study revealed that females were heavier than males, which is typically explained by fecundity selection for large body size in females, as both traits are often positively related (Honek, 1993; Blanckenhorn, 2000). Accordingly, the difference in mass between the sexes was caused by variation in abdomen mass (and concomitantly absolute fat content), enabling high fecundity and large energy reserves to fuel egg production in females (Eaton, 1988; Tammaru et al., 1996; Berwaerts et al., 2002). This in turn results in a higher wing loading in females, which increases the cost of flying (Wickman, 2009; Saastamoinen et al., 2012). In contrast, male insects usually develop faster and emerge as adults earlier (protandry) to maximize mating opportunities, which may be traded off against body size (Wiklund \& Fagerström, 1977; Fischer \& Fiedler, 2000b; Karl \& Fischer, 2008a).

Also, sexes typically differ with regard to selection pressures on flight performance in insects, which may result in sex-specific morphologies (Gilchrist, 1990; Van Dyck \& Wiklund, 2002; Merckx \& Van Dyck, 2005; Berwaerts et al., 2006). Male insects often spend much more time in flight locating mates or fighting rivals (Wickman, 1992; Saastamoinen et al., 2012). Females, in contrast, fly more slowly and cover relatively short distances per bout, such as from one nectar or host plant to another (Shreeve, 1986; Berwaerts et al., 2006; Reim et al., 2018a). This latter type of flight may benefit from low aspect ratios and therefore wider wings (Betts \& Wootton, 1988; Berwaerts et al., 2002; Karl et al., 2008b; Hassall, 2015). Accordingly, we found clear morphological differences between the sexes as predicted, with females having wider wings, as indicated by a lower wing aspect ratio, compared with males, resulting in larger wing areas. Males, in contrast, had relatively long and elongated wings, which has been shown to increase acceleration (Berwaerts et al., 2002; Berwaerts \& Van Dyck, 2004). Additionally, thorax mass and thoraxabdomen ratio were higher in males, which may increase their flight performance (Berwaerts et al., 2002; Berwaerts \& Van Dyck, 2004; Karl et al., 2008b). Finally, relative fat content was higher in males, perhaps to fuel the high flight activity (Zera et al., 1998; Karl et al., 2008b). In summary, males showed morphologies indicative of increased flight performance in agreement with hypothesis 1, which may be beneficial in male-male competition and mate location (Davies, 1978; Fischer \& Fiedler, 2000b; Saastamoinen et al., 2012). These conclusions rest on laboratory-reared animals, but very likely also apply in nature (Van Dyck \& Wiklund, 2002; Günter et al., 2019).

\section{Sexual differences in flight behaviour and capacity}

We only found a sexual difference in the number of squares visited, with females approaching more positions than males, but not in the total distance moved or step length. While we had no clear predictions regarding step length, we expected females to fly greater total distances. It is likely, however, that the restricted space in the climate cell was not suitable for revealing such a difference. Anyway, the difference in the number of squares visited fits hypothesis 3 and the results of studies on L. tityrus under semi-natural conditions (Reim et al., 2018b). While males typically show a high flight activity, they are more bound to specific places than females due to their territorial behaviour (Fischer \& Fiedler, 2001; Reim et al., 2018b, c). Females, in contrast, often fly less, but do not tend to return to specific places. Rather, they move through the landscape in search of nectar necessary for egg production and oviposition sites (Arrese \& Soulages, 2010; Karl et al., 2011; Reim et al., 2018a). Additionally, females may try to escape male harassment (Hovestadt \& Nieminen, 2009; Trochet et al., 2013). Surprisingly, flight performance did not differ significantly among the sexes, which is contrary to what is reported for this species (thus challenging hypothesis 2; Reim et al., 2018c, 2019a). One reason might be that butterflies were tested only after the flight experiment in the climate cabinet, which may have introduced variation among individuals. We exclusively used freshly emerged and unmated butterflies in our study. Thus, the results obtained may differ if using mated butterflies or other age classes. However, dispersal and emigration propensity in butterflies and probably other insects seems not to be strongly related to age (Baguette et al., 2014; Reim et al., 2018 b). Furthermore, L. tityrus is very territorial (Reim et al., 2018b, 2018c), which is unlikely to change with age (Fischer et al., 1999; Fischer \& Fiedler, 2001).

Regarding the influence of morphological traits, we found that movement was linked to body size and wing length, and flight performance to body size and wing aspect ratio in females. Smaller and thus lighter individuals tended to be the most mobile, probably due a reduced need for energy for flight (Berwaerts \& Van Dyck, 2004; Reim et al., 2018b). It is likely that the same reasoning applies to the fact that smaller females showed a better flight performance. Furthermore, the females' flight performance was reduced when covering longer distances and approaching more positions in the experimental chamber, potentially as a result of exhaustion and resource depletion. Males making longer steps had a better performance in the vortex test, indicating that both proxies of flight performance are positively correlated. As in any laboratory study, the question is to what extent these findings apply to natural situations. Potential caveats are that laboratory rearing may induce slightly different phenotypes, and that the space used to explore flight behaviour was very restricted. Nevertheless, this study revealed mainly clear and interpretable results.

\section{CONCLUSIONS}

This study revealed sexual differences in morphology and partly in flight behaviour, with females approaching more positions than males. Thus, females tended to be more mobile, although males showed morphologies typically associated with increased flight performance (Gilchrist, 1990; Berwaerts et al., 2006; Saastamoinen et al., 2012; Ducatez et al., 2014). We believe that this discrepancy results from the territorial behaviour of male L. tityrus 
(Fischer \& Fiedler, 2001; Reim et al., 2018b, c). Therefore, males show a high flight activity (Reim et al., 2018a), but tend to come back to the same spot, while females search for nectar and oviposition sites. Accordingly, female $L$. tityrus have been shown to have a higher dispersal propensity than males (Reim et al., 2018b). These results indicate that an extrapolation from flight capacity to actual patterns of movement is very difficult, as the latter are subject to a variety of influences including environmental conditions and motivation.

ACKNOWLEDGEMENTS. This research was funded by the DFG research training group RESPONSE (DFG GRK 2010).

\section{REFERENCES}

Almbro M. \& Kullberg C. 2012: Weight loading and reproductive status affect the flight performance of Pieris napi butterflies. - J. Insect Behav. 25: 441-452.

Arrese E.L. \& Soulages J.L. 2010: Insect fat body: Energy, metabolism, and regulation. - Annu. Rev. Entomol. 55: 207-225.

Baguette M., Stevens V.M. \& Clobert J. 2014: The pros and cons of applying the movement ecology paradigm for studying animal dispersal. - Mov. Ecol. 2: 1-13.

BERWAERTS K. \& VAN DYCK H. 2004: Take-off performance under optimal and suboptimal thermal conditions in the butterfly $\mathrm{Pa}$ rarge aegeria. - Oecologia 141: 536-545.

Berwaerts K., Van Dyck H. \& Aerts P. 2002: Does flight morphology relate to flight performance? An experimental test with the butterfly Pararge aegeria. - Funct. Ecol. 16: 484-491.

Berwaerts K., Aerts P. \& Van Dyck H. 2006: On the sex-specific mechanisms of butterfly flight: Flight performance relative to flight morphology, wing kinematics, and sex in Pararge aegeria. - Biol. J. Linn. Soc. 89: 675-687.

BetTs C.R. \& Wootton R.J. 1988: Wing shape and flight behaviour in butterflies (Lepidoptera: Papilionoidea and Hesperioidea): A preliminary analysis. - J. Exp. Biol. 138: 271-288.

BlanCKENHORN W.U. 2000: The evolution of body size. What keeps organisms small? - Quart. Rev. Biol. 75: 385-407.

Bohonak A.J. 1999: Dispersal, gene flow, and population structure. - Quart. Rev. Biol. 74: 21-45.

Bonte D., Van Dyck H., Bullock J.M., Coulon A., Delgado M., Gibbs M., Lehouck V., Matthysen E., Mustin K. \& SaastaMOINEN M. ET AL. 2012: Costs of dispersal. - Biol. Rev. 87: 290-312.

Brunzel S., Bussmann M. \& Obergruber H. 2008: Deutliche Veränderungen von Tagfalterzönosen als Folge von Ausbreitungsprozessen. Erste Ergebnisse eines Monitorings über 17 Jahre. - Natur Landsch. 6: 280-287.

Cote J., Clobert J., Brodin T., Fogarty S. \& Sih A. 2010a: Personality-dependent dispersal: Characterization, ontogeny and consequences for spatially structured populations. - Philos. Trans. R. Soc. (B) 365: 4065-4076.

Cote J., Fogarty S., Weinersmith K., Brodin T. \& Sih A. 2010b: Personality traits and dispersal tendency in the invasive mosquitofish (Gambusia affinis). — Proc. R. Soc. (B) 277: 15711579.

DAVIES N.B. 1978: Territorial defence in the speckled wood butterfly (Pararge aegeria): The resident always wins. - Anim. Behav. 26: 138-147.

Dingemanse N.J., Both C., van NoordwiJk A.J., Rutten A.L. \& DRENT P.J. 2003: Natal dispersal and personalities in great tits (Parus major). - Proc. R. Soc. (B) 270: 741-747.

Ducatez S., Legrand D., Chaput-Bardy A., Stevens V.M., FrÉviLLE H. \& BAGUETTE M. 2012: Inter-individual variation in movement: Is there a mobility syndrome in the large white butterfly Pieris brassicae? - Ecol. Entomol. 37: 377-385.

Ducatez S., Baguette M., Trochet A., Chaput-Bardy A., Legrand D., Stevens V. \& Fréville H. 2013: Flight endurance and heating rate vary with both latitude and habitat connectivity in a butterfly species. - Oikos 122: 601-611.

Ducatez S., Humeau A., Congretel M., Fréville H. \& Baguette M. 2014: Butterfly species differing in mobility show different structures of dispersal-related syndromes in the same fragmented landscape. - Ecography 37: 378-389.

Duckworth R.A. \& Badyaev A.V. 2007: Coupling of dispersal and aggression facilitates the rapid range expansion of a passerine bird. - Proc. Natl. Acad. Sci. U.S.A. 104: 15017-15022.

Dudley R. 2000: The Biomechanics of Insect Flight. Princeton University Press, Pinceton, 496 pp.

Eaton J.L. 1988: Lepidopteran Anatomy. John Wiley and Sons, New York, 257 pp.

EBert G. \& Rennwald E. 1991: Die Schmetterlinge Baden-Württembergs. Vol. 2. Ulmer, Stuttgart, 535 pp.

FisCHER K. \& FiedLER K. 2000a: Methodische Aspekte von FangWiederfangstudien am Beispiel der Feuerfalter Lycaena helle und L. hippothoe. - Beitr. Ökol. 4: 157-172.

FisCHER K. \& FiedLER K. 2000b: Sex-related differences in reaction norms in the butterfly Lycaena tityrus (Lepidoptera: Lycaenidae). - Oikos 90: 372-380.

Fischer K. \& FiedLer K. 2001: Resource-based territoriality in the butterfly Lycaena hippothoe and environmentally induced behavioural shifts. - Anim. Behav. 61: 723-732.

Fischer K., Beinlich B. \& Plachter H. 1999: Population structure, mobility and habitat preferences of the violet copper $L y$ caena helle (Lepidoptera: Lycaenidae) in Western Germany: Implications for conservation. - J. Insect Conserv. 52: 43-52.

Fischer K., Brakefield P.M. \& ZwaAn B.J. 2003: Plasticity in butterfly egg size: Why larger offspring at lower temperatures? -Ecology 84: 3138-3147.

Fraser D.F., Gilliam J.F., Daley M.J., Le A.N. \& Skalski G.T. 2001: Explaining leptokurtic movement distributions: Intrapopulation variation in boldness and exploration. - Am. Nat. 158: $124-135$.

GILCHRIST G.W. 1990: The consequences of sexual dimorphism in body size for butterfly flight and thermoregulation. - Funct. Ecol. 4: 475-487.

Günter F., Beaulieu M., Brunetti M., Lange L., Schmitz Ornés A. \& FisCHER K. 2019: Latitudinal and altitudinal variation in ecologically important traits in a widespread butterfly. - Biol. J. Linn. Soc. 20: 1-14.

Hassall C. 2015: Strong geographical variation in wing aspect ratio of a damselfly, Calopteryx maculata (Odonata: Zygoptera). - Peer J. 3: e1219, 13 pp.

Hill J.K., Thomas C.D. \& Blakeley D.S. 1999: Evolution of flight morphology in a butterfly that has recently expanded its geographic range. - Oecologia 121: 165-170.

HONEK A. 1993: Intraspecific variation in body size and fecundity in insects: A general relationship. — Oikos 66: 483-492.

HOPPER K.R. 1999: Risk-spreading and bet-hedging in insect population biology. - Annu. Rev. Entomol. 44: 535-560.

Hovestadt T. \& Nieminen M. 2009: Costs and benefits of dispersal in butterflies. In Settele J., Shreeve T., Konvička M. \& Van Dyck H. (eds): Ecology of Butterflies in Europe. Cambridge University Press, Cambridge, pp. 97-106.

Hughes C.L., Hill J.K. \& Dytham C. 2003: Evolutionary tradeoffs between reproduction and dispersal in populations at expanding range boundaries. - Proc. R. Soc. (B) 270: S147S150. 
KARL I. \& FISCHER K. 2008a: Why get big in the cold? Towards a solution to a life-history puzzle. - Oecologia 155: 215-225.

KarL I., JANOwitz S.A. \& Fischer K. 2008b: Altitudinal life-history variation and thermal adaptation in the copper butterfly Lycaena tityrus. - Oikos 117: 778-788.

Karl I., Stoks R., De Block M., Janowitz S.A. \& Fischer K. 2011: Temperature extremes and butterfly fitness: Conflicting evidence from life history and immune function. - Glob. Change Biol. 17: 676-687.

Kunssaari M., Rytteri S., Heikkinen R.K., Helio J. \& von Bagh P. 2016: Weather explains high annual variation in butterfly dispersal. - Proc. R. Soc. (B) 283: 20160413, 8 pp.

Legrand D., Trochet A., Moulherat S., Calvez O., Stevens V.M., Ducatez S., Clobert J. \& Baguette M. 2015: Ranking the ecological causes of dispersal in a butterfly. - Ecography 38: $822-831$.

Matthysen E. 2012: Multicausality of dispersal: A review. In Clobert J., Baguette M., Benton T.G. \& Bullock J.M. (eds): Dispersal Ecology and Evolution. Oxford University Press, Oxford, pp. 1-18.

Merckx T. \& VAN Dyck H. 2005: Mate location behaviour of the butterfly Pararge aegeria in woodland and fragmented landscapes. - Anim. Behav. 70: 411-416.

Nittepõld K., Smith A.D., Osborne J.L., Reynolds D.R., Carreck N.L., Martin A.P., Marden J.H., Ovaskainen O. \& HanSKI I. 2009: Flight metabolic rate and Pgi genotype influence butterfly dispersal rate in the field. - Ecology 90: 2223-2232.

Réale D., Garant D., Humphries M.M., Bergeron P., Careau V. \& Montiglio P.O. 2010: Personality and the emergence of the pace-of-life syndrome concept at the population level. Philos. Trans. R. Soc. (B) 365: 4051-4063.

Reim E., Arnstedt I., Barwisch I., Baumgarten M., Bock S., Eberspach J., Ellerbrok J., Gebremeskel M., Küpper S., Guth L. ET AL. 2018a: Movement patterns differ between sexes and depend on weather conditions in the butterfly Lycaena tityrus. - J. Insect Behav. 31: 309-320.

Reim E., Baguette M., GÜNTer F. \& Fischer K. 2018b: Emigration propensity and flight performance are decoupled in a butterfly. - Ecosphere 9: e2502, 17 pp.

Reim E., Blesinger S., Förster L. \& Fischer K. 2018c: Successful despite poor flight performance: range expansion is associated with enhanced exploratory behaviour and fast development. - J. Evol. Biol. 31: 1165-1179.

Reim E., EichHorn D., Roy J.D., Steinhoff P.O.M. \& Fischer K. 2019a: Nutritional stress reduces flight performance and exploratory behavior in a butterfly. - Insect Sci. 26: 897-910.

Reim E., Kahl S., MetschKe K. \& Fischer K. 2019b: Sexual differences rather than flight performance underlie movement patterns and exploration in a tropical butterfly. - Ecol. Entomol. 44: 648-658.

Ronce O. 2007: How does it feel to be like a rolling stone? Ten questions about dispersal evolution. - Annu. Rev. Ecol. Evol. Syst. 38: 231-253.
SAASTAMOINEn M. \& HANSKI I. 2008: Genotypic and environmental effects on flight activity and oviposition in the Glanville Fritillary butterfly. - Am. Nat. 171: 701-712.

SaAstamoinen M., Brakefield P.M. \& Ovaskainen O. 2012: Environmentally induced dispersal-related life-history syndrome in the tropical butterfly, Bicyclus anynana. - J. Evol. Biol. 25: 2264-2275.

Saastamoinen M., Bocedi G., Cote J., Legrand D., Guillaume F., Wheat C.W., Fronhofer E.A., Garcia C., Henry R. \& Husby A. ET AL. 2018: Genetics of dispersal. — Biol. Rev. 93: 574 599.

Settele J., Kudrna O., Harpke A., Kühn I. \& Van Swaay C. 2008: Climatic Risk Atlas of European Butterflies. Biodiversity and Ecosystem Risk Assessment 1. Pensoft, Sofia, 712 pp.

SHREEVE T. 1986: Egg-laying by the speckled wood butterfly ( $\mathrm{Pa}$ rarge aegeria): The role of female behaviour, host plant abundance and temperature. - Ecol. Entomol. 11: 229-236.

Steyn V.M., Mitchell K.A. \& Terblanche J.S. 2016: Dispersal propensity, but not flight performance, explains variation in dispersal ability. - Proc. R. Soc. (B) 283: 20160905, 9 pp.

Tammaru T., Kaitaniemi P. \& Ruohomaki K. 1996: Realized fecundity in Epirrita autumnata (Lepidoptera: Geometridae): Relation to body size and consequences to population dynamics. - Oikos 77: 407-416.

Therry L., Zawal A., Bonte D. \& Stoks R. 2014: What factors shape female phenotypes of a poleward-moving damselfly at the edge of its range? - Biol. J. Linn. Soc. 112: 556-568.

Tolman T. \& Lewington R. 1998: Die Tagfalter Europas und Nordwestafrikas. Franckh-Kosmos, Stuttgart, 319 pp.

Trochet A., Legrand D., Larranaga N., Ducatez S., Calvez O., Cote J., Clobert J. \& Baguette M. 2013: Population sex ratio and dispersal in experimental, two-patch metapopulations of butterflies. - J. Anim. Ecol. 82: 946-955.

VAn Dyck H. \& Baguette M. 2005: Dispersal behaviour in fragmented landscapes: routine or special movements? - Basic Appl. Ecol. 6: 535-545.

VAN Dyck H. \& WiKLund C. 2002: Seasonal butterfly design: Morphological plasticity among three developmental pathways relative to sex, flight and thermoregulation. - J. Evol. Biol. 15: 216-225.

WickMAn P.O. 1992: Sexual selection and butterfly design - a comparative study. - Evolution 46: 1525-1536.

WiCKMAN P.O. 2009: Thermoregulation and habitat use in butterflies. In Settele J., Shreeve T.G., Konvicka M. \& Van Dyck H. (eds): Ecology of Butterflies in Europe. Cambridge University Press, Cambridge, pp. 55-61.

WikLUnd C. \& FAgERSTRÖM T. 1977: Why do males emerge before females? - Oecologia 31: 153-158.

Zera A.J., Potts J. \& Kobus K. 1998: The physiology of lifehistory trade-offs: Experimental analysis of a hormonally induced life-history trade-off in Gryllus assimilis. - Am. Nat. 152: 7-23.

Received April 4, 2019; revised and accepted November 13, 2019 Published online December 9, 2019 
Table A1. Correlations among morphological parameters in L. tityrus. Given are correlation coefficients ( $r$ ) with significant correlations in bold.

\begin{tabular}{|c|c|c|c|c|c|c|c|c|c|c|c|}
\hline & $\begin{array}{l}\text { Adult body } \\
\text { mass at } \\
\text { emergence }\end{array}$ & $\begin{array}{l}\text { Adult } \\
\text { body } \\
\text { mass }\end{array}$ & $\begin{array}{l}\text { Abdomen } \\
\text { mass }\end{array}$ & $\begin{array}{c}\text { Thorax } \\
\text { mass }\end{array}$ & $\begin{array}{l}\text { Thorax- } \\
\text { abdomen } \\
\text { ratio }\end{array}$ & Fat $(\%)$ & Fat (mg) & $\begin{array}{l}\text { Wing } \\
\text { length }\end{array}$ & $\begin{array}{l}\text { Wing } \\
\text { area }\end{array}$ & $\begin{array}{l}\text { Wing } \\
\text { loading }\end{array}$ & $\begin{array}{c}\text { Aspect } \\
\text { ratio }\end{array}$ \\
\hline $\begin{array}{l}\text { Adult body mass } \\
\text { at emergence }\end{array}$ & 1.000 & 0.686 & 0.671 & 0.272 & -0.510 & 0.352 & -0.166 & 0.440 & 0.585 & 0.589 & -0.404 \\
\hline Adult body mass & 0.686 & 1.000 & 0.907 & 0.513 & -0.693 & 0.554 & -0.183 & 0.490 & 0.708 & 0.935 & -0.538 \\
\hline Abdomen mass & 0.671 & 0.907 & 1.000 & 147 & -0.883 & 0.526 & -0.349 & 0.304 & 0.630 & 0.846 & -0.647 \\
\hline Thorax mass & 0.272 & 0.513 & 0.147 & 1.000 & 0.163 & 0.216 & 0.234 & 0.538 & 0.370 & 0.493 & 0.082 \\
\hline Thorax-abdomen ratio & -0.510 & -0.693 & -0.883 & 163 & 1.000 & -0.505 & 0.351 & -0.109 & -0.506 & -0.643 & 0.698 \\
\hline Fat $(\%)$ & 0.353 & 0.554 & 0.526 & 0.216 & -0.505 & 1.000 & 0.471 & 0. & & 0.4 & -0.517 \\
\hline Fat (mg) & -0.166 & -0.183 & -0.349 & 0.234 & 0.351 & 0.471 & 1.000 & 0.033 & -0.091 & -0.18 & 0.179 \\
\hline Wing & 0.440 & 0.490 & 304 & 0.538 & -0.109 & 0.304 & 0.033 & 1.000 & 0.7 & 12 & -0.027 \\
\hline Wing & 0.585 & 0.708 & 630 & 370 & -0.506 & 0.549 & -0.091 & 799 & & 8 & 621 \\
\hline Wing & 0.589 & 0.935 & 846 & 493 & -0.643 & 0.434 & -0.188 & & 0.418 & 1.000 & -0.382 \\
\hline Aspect ratio & -0.404 & 0.538 & 647 & 0.082 & 0.698 & -0.517 & 0.179 & -0.027 & -0.621 & -0.382 & 1.000 \\
\hline
\end{tabular}

Table A2. Results of $\mathrm{Chi}^{2}$ tests testing for significant differences in the distribution of all butterflies, males and females within the experimental chamber (observed versus expected; expected = equal frequencies). Fields $\mathrm{C}, \mathrm{H}, \mathrm{J}, \mathrm{K}$, and $\mathrm{R}$ (in bold) provided food and plants for oviposition.

\begin{tabular}{|c|c|c|c|c|c|c|c|c|c|c|c|c|}
\hline \multirow[b]{2}{*}{ Field } & \multicolumn{4}{|c|}{ All individuals } & \multicolumn{4}{|c|}{ Males } & \multicolumn{4}{|c|}{ Females } \\
\hline & $\begin{array}{l}\text { Observed } \\
\text { frequency }\end{array}$ & $\begin{array}{l}\text { Excepted } \\
\text { frequency }\end{array}$ & $\begin{array}{l}\text { Frequency } \\
\text { (observed } \\
\text {-expected) }\end{array}$ & $x^{2}$ & $\begin{array}{l}\text { Observed } \\
\text { frequency }\end{array}$ & $\begin{array}{l}\text { Excepted } \\
\text { frequency }\end{array}$ & $\begin{array}{l}\text { Frequency } \\
\text { (observed } \\
\text {-expected) }\end{array}$ & $x^{2}$ & $\begin{array}{l}\text { Observed } \\
\text { frequency }\end{array}$ & $\begin{array}{l}\text { Excepted } \\
\text { frequency }\end{array}$ & $\begin{array}{c}\text { Frequency } \\
\text { (observed } \\
\text { - expected) }\end{array}$ & $x^{2}$ \\
\hline A & 49 & 43 & 6 & 0.84 & 32 & 26 & 6 & 1.38 & 17 & 16 & 1 & 0.06 \\
\hline B & 33 & 43 & -10 & 2.33 & 24 & 26 & -2 & 0.15 & 9 & 16 & -7 & 3.06 \\
\hline C & 39 & 43 & -4 & 0.37 & 25 & 26 & -1 & 0.04 & 14 & 16 & -2 & 0.25 \\
\hline $\mathrm{D}$ & 43 & 43 & 0 & 0.00 & 30 & 26 & 4 & 0.62 & 13 & 16 & -3 & 0.56 \\
\hline E & 50 & 43 & 7 & 1.14 & 30 & 26 & 4 & 0.62 & 20 & 16 & 4 & 1.00 \\
\hline $\mathrm{F}$ & 54 & 43 & 11 & 2.81 & 32 & 26 & 6 & 1.38 & 22 & 16 & 6 & 2.25 \\
\hline G & 8 & 43 & -35 & 28.49 & 4 & 26 & -22 & 18.62 & 4 & 16 & -12 & 9.00 \\
\hline H & 14 & 43 & -29 & 19.56 & 5 & 26 & -21 & 16.96 & 9 & 16 & -7 & 3.06 \\
\hline I & 11 & 43 & -32 & 23.81 & 9 & 26 & -17 & 11.12 & 2 & 16 & -14 & 12.25 \\
\hline J & 23 & 43 & -20 & 9.30 & 15 & 26 & -11 & 4.65 & 8 & 16 & -8 & 4.00 \\
\hline K & 67 & 43 & 24 & 13.40 & 38 & 26 & 12 & 5.54 & 29 & 16 & 13 & 10.56 \\
\hline $\mathrm{L}$ & 14 & 43 & -29 & 19.56 & 10 & 26 & -16 & 9.85 & 4 & 16 & -12 & 9.00 \\
\hline M & 9 & 43 & -34 & 26.88 & 7 & 26 & -19 & 13.88 & 2 & 16 & -14 & 12.25 \\
\hline $\mathrm{N}$ & 10 & 43 & -33 & 25.33 & 5 & 26 & -21 & 16.96 & 5 & 16 & -11 & 7.56 \\
\hline 0 & 39 & 43 & -4 & 0.37 & 17 & 26 & -9 & 3.12 & 22 & 16 & 6 & 2.25 \\
\hline$P$ & 118 & 43 & 75 & 130.81 & 72 & 26 & 46 & 81.38 & 46 & 16 & 30 & 56.25 \\
\hline Q & 75 & 43 & 32 & 23.81 & 46 & 26 & 20 & 15.38 & 29 & 16 & 13 & 10.56 \\
\hline $\mathbf{R}$ & 68 & 43 & 25 & 14.53 & 41 & 26 & 15 & 8.65 & 27 & 16 & 11 & 7.56 \\
\hline$S$ & 45 & 43 & 2 & 0.09 & 27 & 26 & 1 & 0.04 & 18 & 16 & 2 & 0.25 \\
\hline $\mathrm{T}$ & 86 & 43 & 43 & 43.00 & 59 & 26 & 33 & 41.88 & 27 & 16 & 11 & 7.56 \\
\hline$\Sigma$ & 855 & 860 & -5 & 386.44 & 528 & 520 & 8 & 252.23 & 327 & 320 & 7 & 159.31 \\
\hline
\end{tabular}
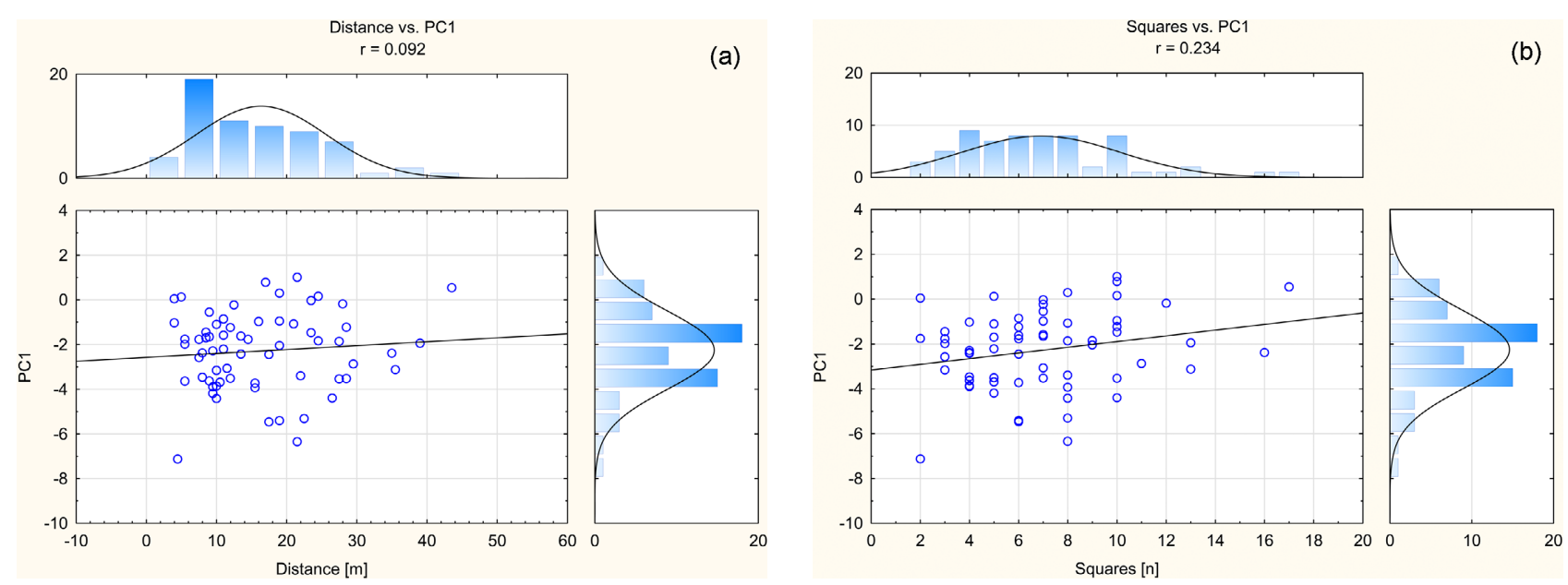

Fig. A1. Relationships between the variables (a) distance and PC1 (males), (b) squares visited and PC1 (males), (c) squares visited and PC3 (males), (d) Vortex test and squares visited (females), (e) squares visited and PC1 (females), (f) Vortex test and step length (males), and $(\mathrm{g})$ Vortex test and PC1 (females). 

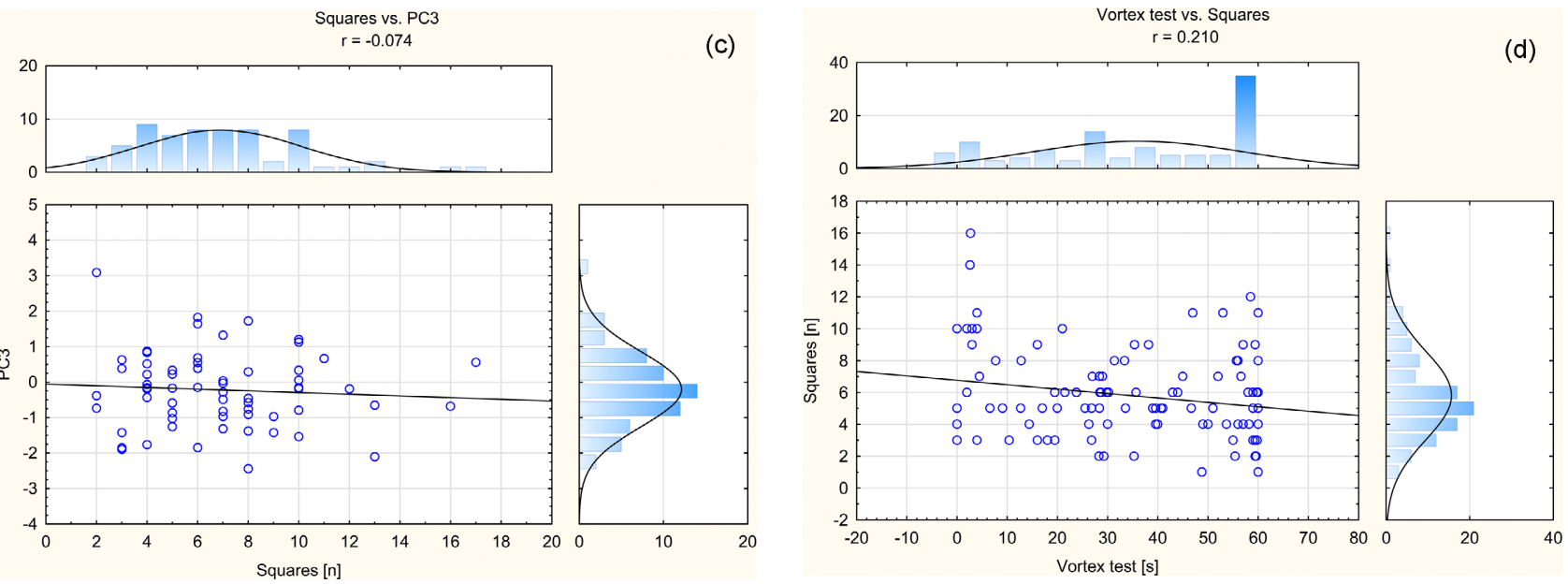

Squares vs. PC $r=0.287$

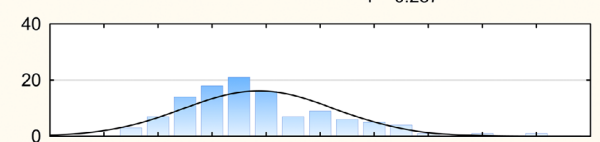

(e)
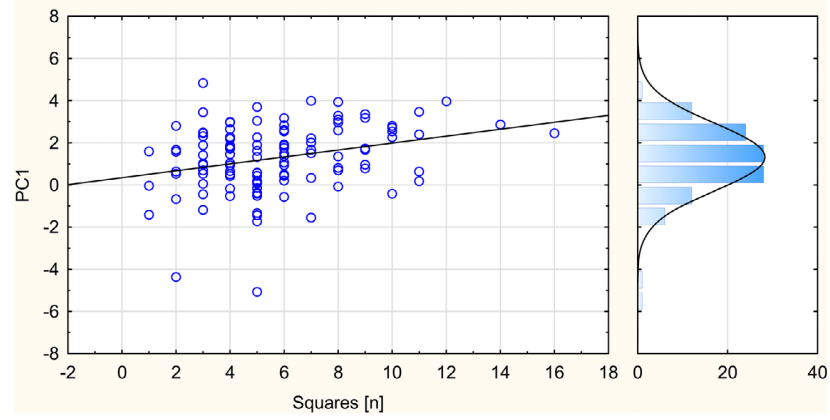

Vortex test vs. PC1 $r=-0.143$
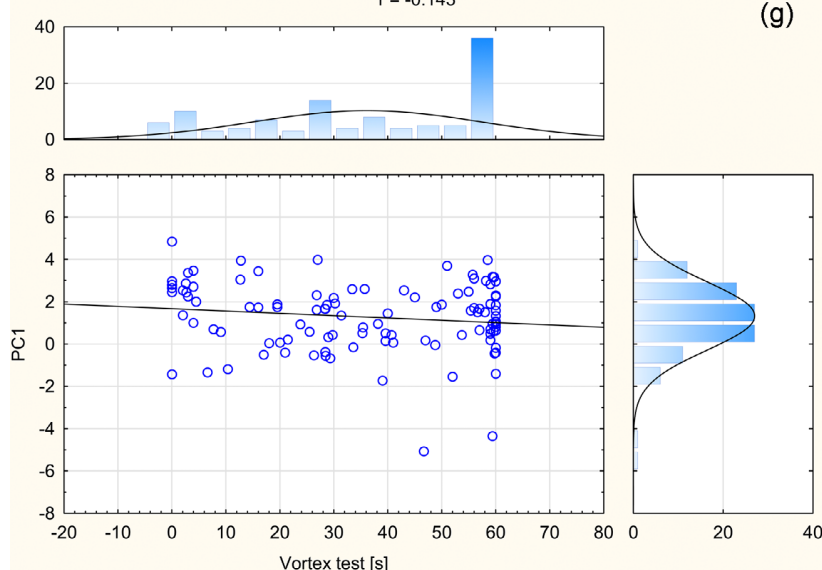

Vortex test vs. Step length $r=0.110$
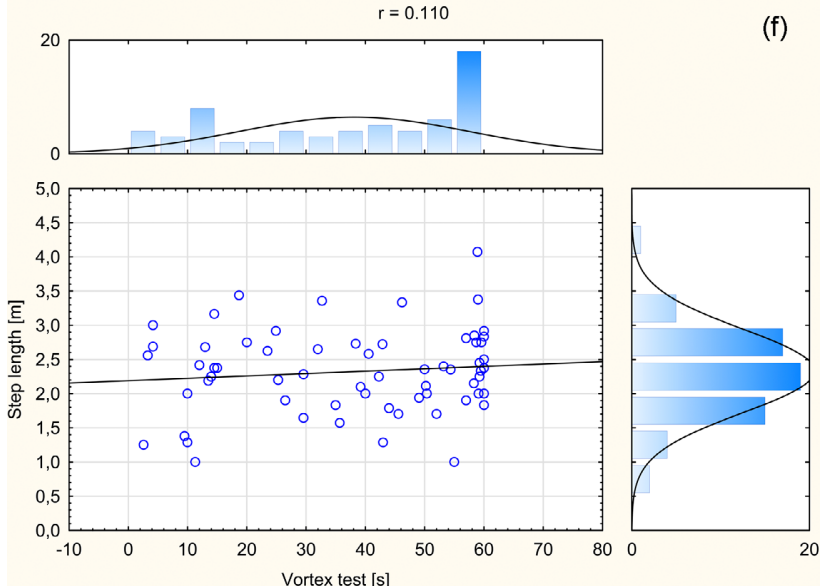

(g) 